UDK: 005.44:330.34

DOI: $10.2478 / j c b t p-2018-0004$
Milenko Popović *

\section{Technological Progress, Globalization, and Secular Stagnation}

\begin{abstract}
After the 2008 crisis, despite economic recovery that started in 2009, the world economy has experienced a downward shift of its growth path and a consequent decline. As shown at the beginning of this paper, this shift and growth rate stagnation are totally attributable to the economic dynamics in developed economies, the USA and the EU. Explanations of this phenomenon can be divided into two large groups: explanations that belong to the demand side and those that belong to the supply side. The aim of this paper is to give a critical survey of the most important explanations for the ongoing growth stagnation in developed countries and consequently in the entire world economy. This ongoing prolonged stagnation can only be explained by looking at both, the demand and supply sides of the explanation, and particularly by taking a closer look at the interaction between aggregate demand and aggregate supply. In other words, secular stagnation manifests itself as a problem of the limitation of long run growth of aggregate demand. However, in order to explain the causes of those demand limitations, we have to undertake a careful analysis of the supply side dynamics, especially the dynamics of innovations, which bring us to circular and cumulative causation. In order to explain the numerous consequences of this stagnation and to solve some important puzzles, like the productivity paradox for example, a special emphasis is given to the analysis of deindustrialization and the consequent strange reoccurrence of a dual economy within most developed countries during the period of the IT revolution and hyper-globalization. It will also be shown that this new dual economy presents serious limitations for further technological advancement and economic development, quite contrary to the old dualism which contributed to an acceleration of economic growth.
\end{abstract}

Keywords: Secular stagnation, Economic growth, Dual economy, Technological progress, Globalization, Inequalities

JEL Classification: O30, O40, E30
${ }^{*}$ Professor at Mediterranean

University, Faculty for Business

Studies, Podgorica, Montenegro

Email:

milenko.popovic@unimediteran.net 


\section{Introduction}

Despite the economic recovery that started in 2009, the world economy has been so strongly hit by the 2007 Great Recession that its growth path dropped significantly causing a decline in the rate of economic growth and prolonged stagnation. As shown in the next section, this shift and growth rate stagnation are totally attributable to the economic dynamics in developed economies, the USA and the EU. So far, less developed and developing countries do not show any sign of stagnation. The main purpose of this paper is to provide a critical review of the most important explanations offered so far in explaining the causes of this ongoing growth stagnation in developed countries and, in that way, in the whole world economy. In doing so, particular emphasis will be given to the thesis that both approaches developed so far, the supply and demand sides, should be regarded in their interaction, using the approach of circular and cumulative causation.

The following section is devoted to the statistical illustration and visualisation of the growth path shift and the growth rate stagnation in the world economy. The third section of the paper will be devoted to critical review of the supply side explanations of stagnation. Also, some new supply side insights referring to dynamics of innovative processes in the past several decades will be offered. The forth section is devoted to the critical review of the demand side of the explanation. This is, no doubt, the most important and most critical part of the whole scientific discourse regarding ongoing stagnation. It is in fact so important and so critical that the majority of authors agree that if this hypothesis is true, than we need an entirely new Macroeconomics. The fifth section deals with deeper and long run factors that explain aggregate demand stagnation. Since those factors are on the supply side, this section is devoted to the demand-supply interactions that have prevailed in the past several decades, or to the above mentioned circular and cumulative causation. In the sixth section, an effort is made to shed a light on the strange reoccurrence of a dual economy in developed countries and to point to possible economic and social problems connected with this phenomenon. In order to explain the numerous consequences of this stagnation and to solve some important puzzles, like the old puzzle of the productivity paradox for example, a particular emphasis is given to the analysis of deindustrialization and the consequent reoccurrence of a dual economy within most developed countries during the period of the IT revolution and hyper-globalization. The paper will end with a short concluding sentence that sums up all of this. 


\section{Growth stagnation}

1. Developed countries, as well as a majority of less developed countries had experienced very strong economic growth during the whole period of globalization or the period of "great moderation", to use a term that a great number of mainstream economists used at that time. Of course, what we are talking about is the period from 1980 until 2008. "Great moderation", as is well known, started with trade liberalization sometime at the beginning of the 1980s and then increased speed with capital account liberalization at the beginning of the 1990s. Almost all mainstream economists used to support this kind of hyper-globalization, to use Dany Rodrik's (2011) words. After 2008, almost all developed countries experienced either a crash or a strong decline followed either by stagnation or a very weak recovery. Being confronted with these facts, mainstream economist finally accepted a much more appropriate name for the crisis that hit the entire world economy in 2008 - The Great Recession.

A closer look at what happened in the world economy and in particular world regions in the last couple of decades can be seen by looking at a series of visualizations made for the respective world regions as well as for the entire world economy. The world economy as well as developed and less developed economies are presented below with two pictures. The first picture presents the actual growth path of GDP in the post crisis period of 2007-2015 and the estimated values of GDP assuming persistence of potential growth path. Several estimates of the potential growth path are given, one using the long term average growth rate for 1970-2008, another for the 1970-2009 period, then 1970-2010, and all years up to 2015 as well. As can be seen, all these estimated versions of potential growth paths are very similar, meaning that our findings are very robust. Second picture presents a long run growth path of the actual GDP matched with two smoothed growth paths obtained by using average growth rates for the entire periods of 1970-2015 and that for the pre-crisis period 1970-2008.

Now, if we take a look at the whole world economy and at developed and less developed economies, shown in the next three graphs, it will be possible to derive some very important conclusions. First, we can notice a pretty significant drop of the growth path of world economy. Measured in the previous way, by looking at the distance of the old and new growth paths in 2015, it can be seen that the growth path of the world economy dropped by 7.2 to 9 percent, depending on assumptions taken in estimating potential growth path.

Second, from the two graphs that follow the previous one and refer to the Developed World (the USA and the rest of Northern America and Europe) and the Rest 
of the World, it can be noticed that a drop in the world economy's growth path is entirely attributable to declines of the U.S. and European economies' growth paths. The growth path for the Rest of the World (Developing economies and Oceania) has not experienced any shift in the period after 2008. On the other hand, the growth path of Developed Economies dropped by13.27 to 16.72 percent, depending on assumptions taken in the projection of potential growth path.

\section{Graph 1: World economy actual and potential growth}

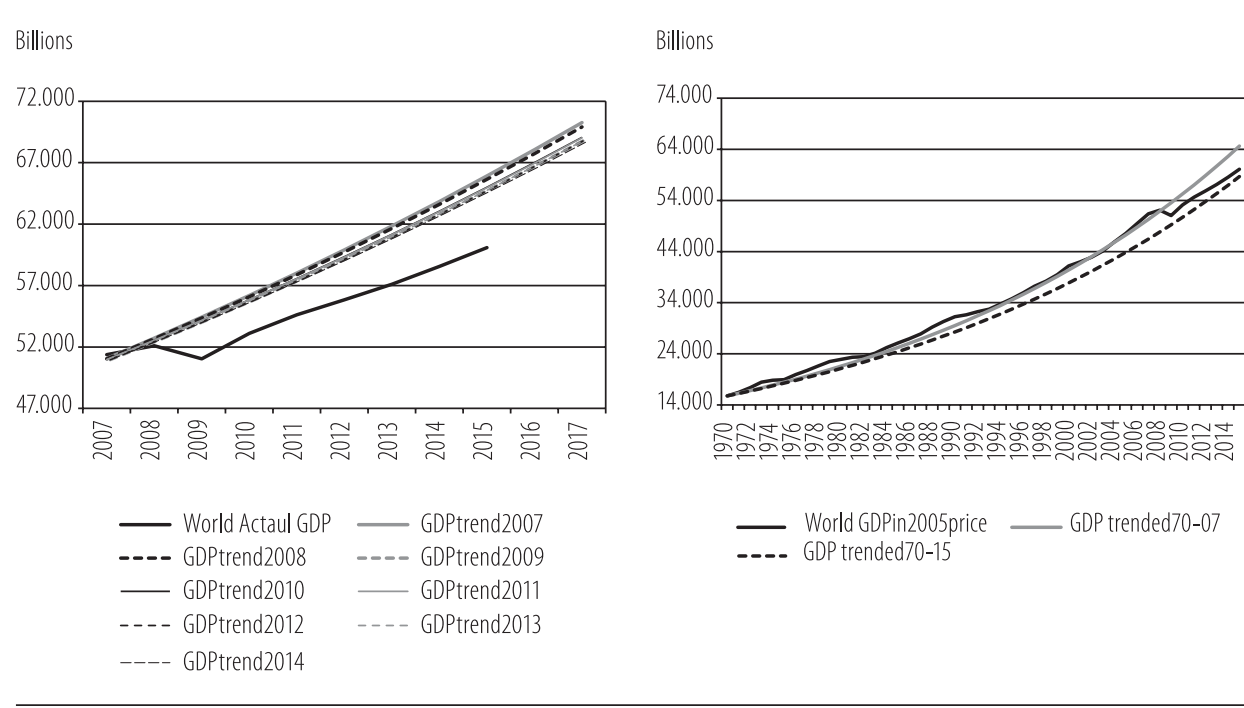

Sources: Authors calculations based on UN Data set.

Finally, in the case of Developed World economies, the slope of the new growth path or its growth rate is much smaller than that on the old growth path. The growth rate for the old growth path for this group of countries was 2.75 percent, while on the new growth path, during the period from the beginning of recovery (2009-2015), it is just 1.72 percent, which is a drop of 1.03 percentage points. Apart from being higher, growth rates for the Rest of the World do not show any decline in the observed periods. On the contrary, in 2009-2015 GDP growth rate was even higher (4.28 percent) than that in the previous period of 1970-2007 (4.12 percent). 
Graph 2: Actual and potential growth in developed countries
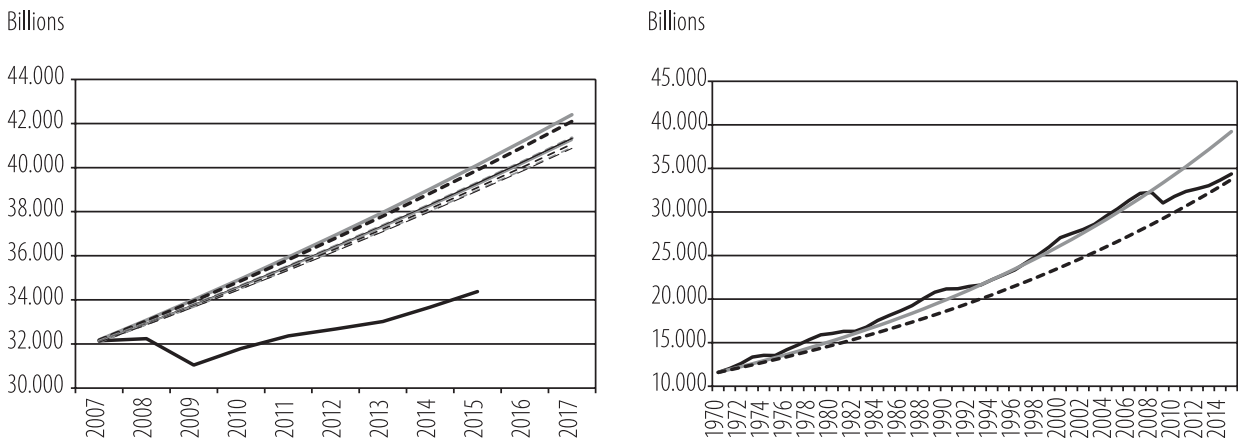

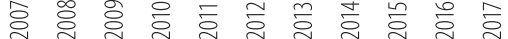

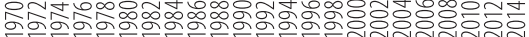

$\begin{array}{ll}\text { - Developed World Actaul GDP } & \text { - GDPtrend2007 } \\ -- \text { GDPtrend2008 } & \text {---- GDPtrend2009 } \\ \text {---- GDPtrend2010 GDPtrend2012 } & \text { - GDPtrend2011 } \\ \text {---- GDPtrend2014 } & \end{array}$

— Developed World GDPin2005price — GDP trended70-07 ---- GDP trended70-15

Sources: Authors calculations based on UN Data set.

\section{Graph 3: Actual and potential growth in developing countries}
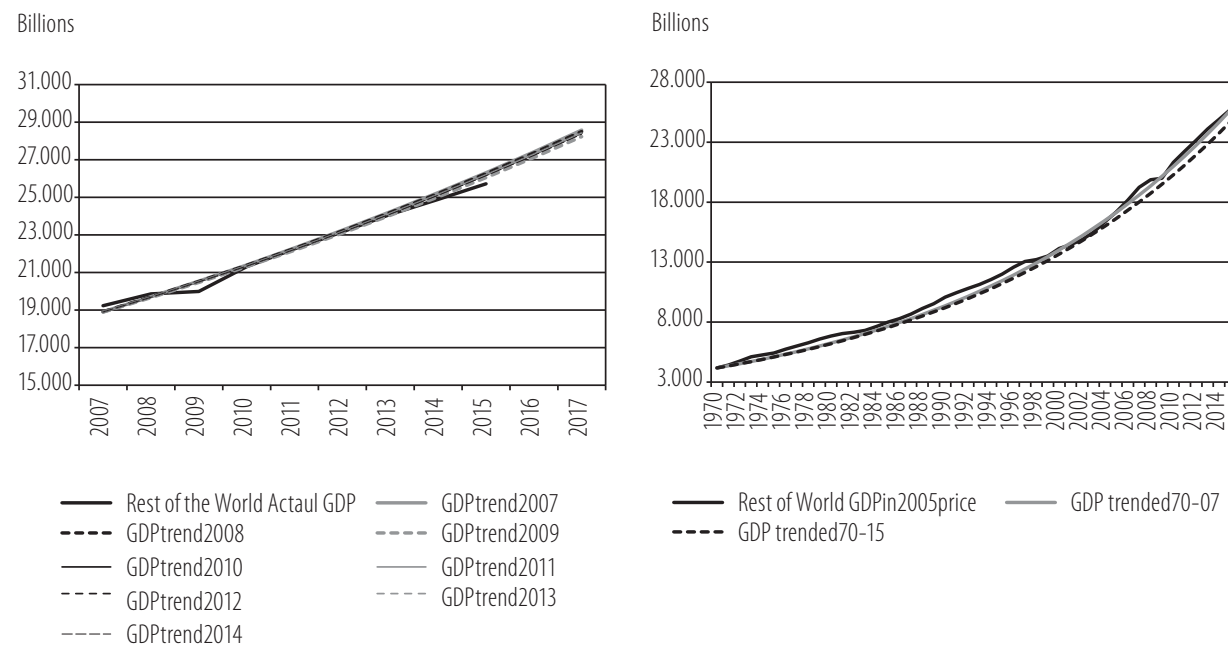

Sources: Authors calculations based on UN Data set. 
2. The graphic presentations and analyses for other world regions, which are not given here for the sake of efficiency, support the previous findings even more that the stagnation of the world economy has been so far entirely attributable to the stagnation of the Developed World. The analysis of growth paths of the USA and developed EU countries shows that despite showing positive growth rates after 2009, both regions as a whole showed a growth path during that period that is much lower than the one which had prevailed in the previous fifty years. In the case of the USA, the difference between the level of GDP implied by the potential growth path in 2015 and the real GDP in that year varies between 14.3 and 17.8 percent depending on assumptions used to estimate potential growth path. Also at the old growth path, the GDP rate of growth used to be 3.09 percent, while at the new growth path it is only 2.03 percent, a decline of 1.06 percentage points.

From the analysis for Europe it can be seen that the drop of the growth path is here also very significant just like that of the US economy. The drop of the GDP growth path is here estimated to be between 13.0 percent and 16.4 percent. On the new growth path, the rate of GDP growth is $1.14 \%$ while on the old one it used to be $2.48 \%$, which is a decline of 1.34 percentage points. The same shape for the growth path characterizes Northern European, Western European, and Southern European economies. Only Eastern Europe has a different shape for the growth path, but only due to the fact that its shape is dominated by so called "transformation recession" which started in the 1990s and ended by the beginning of the millennium (in the sense of Janos Kornai $(1993,1994)$ ). As far as European regions are concerned, the growth path drop phenomenon is most strongly pronounced for the countries of Southern Europe. In fact, the growth path is still dropping there.

Graphs and analyses for Africa, Latin America and Caribbean countries, and for particular regions of Asia and Asia as whole, and for Oceania, do not show any signs of stagnation and, in that way, also show that the rest of the world has not contributed to the stagnation of the world economy. The stagnation of the world economy is, therefore, totally attributable to the economic dynamics in the developed world.

3. It will be very useful for our further analysis to recollect two other very known and old trends in economies of the developed world. They will be of utmost importance in an effort to understand newly discovered trends.

The first one refers to so the called paradox of productivity. In fact, despite the obvious and revolutionary advancement of technology since the beginning of the 1970s, the rate of growth of productivity, either measured by the total factor 
productivity (TFP) or with labour productivity, paradoxically started to decline at exactly the same time. Only partially and only for European countries can this be explained by the fact that the productivity growth rate after WWII until the beginning of the 1970s was extremely strong due to a strong catch-up effect, so that retardation was, in fact, much smaller. Also, only in the decade of 1970s, a decline in productivity growth can be explained by the entry of large numbers of baby boomers into the labour force. It happened both due to the size of baby boomers and due to the high participation of females in the labour force that characterized this generation. So, despite some decent explanations offered so far, the productivity paradox is still one of the most interesting and most important puzzles in economics. Or, as Solow (1987) pointed, computers are "everywhere but in productivity statistics". Indeed, if we take a look at the data for the USA from Table 1, we can notice that the growth rate of TFP in 1972-2014 was 0.70 percent a year which is just one third of that in 1920-1972 period that amounted to 2.01 percent a year. Similarly, the growth of labour productivity dropped from 2.83 in the first observed period to 1.56 percent in the second period. Data for European and other developed countries is even more convincing due to, as already noticed, a stronger catch-up effect in the post-WWII period.

Another well-known trend important to mention and keep in mind is one that refers to the stagnation of wages since the beginning of the 1970s. The exception is the mid-1990s when certain countries experienced a small increase in wages. This trend is very much connected with the previous one. Note that this stagnation of wages is followed by a productivity increase meaning that the whole increase of productivity is captured by the owners of capital. The consequence is a reduction of the labour income share in GDP and growing inequalities.

Table 1: Growth rates in the USA

\begin{tabular}{lrrrr}
\hline USA & Real GDP & Hours Worked & GDP per hour & \multicolumn{1}{c}{ TFP } \\
\hline $1920-1950$ & $3,58 \%$ & $0,61 \%$ & $2,97 \%$ & $2,17 \%$ \\
\hline $1950-1972$ & $3,89 \%$ & $1,24 \%$ & $2,65 \%$ & $1,79 \%$ \\
\hline $1920-1972$ & $3,71 \%$ & $0,88 \%$ & $2,83 \%$ & $2,01 \%$ \\
\hline $1972-1996$ & $3,01 \%$ & $1,63 \%$ & $1,28 \%$ & $0,52 \%$ \\
\hline $1996-2004$ & $3,32 \%$ & $0,81 \%$ & $2,51 \%$ & $1,43 \%$ \\
\hline $2004-2014$ & $1,58 \%$ & $0,36 \%$ & $1,22 \%$ & $0,54 \%$ \\
\hline $1972-2014$ & $2,73 \%$ & $1,17 \%$ & $1,56 \%$ & $0,70 \%$ \\
\hline
\end{tabular}

Source: Calculations based on Gordon's data (2015).

4. There are a lot of interesting questions that follow from these previous considerations. The first and most important question refers to the causes of the obvi- 
ous decline of economic growth in most developed countries. Currently, several interesting hypothesis have been developed which will be examined. The second interesting issue refers to the peculiar fact that developing countries so far have not experienced secular stagnation. And a follow-up question - is this just a slightly longer lag or a substantial phenomenon? Thirdly, what would be the most appropriate policies and policy coordination measures necessary to combat the already encountered or expected growth deceleration in the developed world and, in that way, in the world economy as a whole.

The question regarding the causes of stagnation is, without a doubt, the most important one. It is a prerequisite to solving all other questions. It can be noticed that, as far as the issue of causes of stagnation is concerned, several different explanations have been offered so far. The first one belongs to the real business cycle school and it refers to explanations that insist on the retardation of the potential growth path as the main reason for deceleration of the growth rate. Causes of stagnation, according to this school of thinking, rest on the supply side of economy. The second group of explanations insists on the long term limits of growth that occur due to aggregate demand limitations. According to this explanation, aggregate demand growth path limits the growth of aggregate supply. These two hypotheses will be discussed more extensively later in this paper that is, in fact, predominantly devoted to these two hypotheses.

The third group of explanations refers to the hysteresis hypothesis known in Europe also as Eurosclerosis (Blanchard and Summers, 1986). These explanations focus on the level of growth path and not so much on the slope of growth path or to the growth rate. In this particular situation, the growth path dropped to a lower level compared to the previous one, while the slope of the growth path may very often stay unchanged. A drop of the growth path may occur due to many factors. In the case of hysteresis, a drop of the growth path occurs as a result of damages made by the previous economic crisis to the economic potential of the country or, more precisely, to the Solow-Romer factors of production. Despite the fact that, in general, hysteresis may operate via devastation of any kind of factors of production, in the economic literature on the hysteresis mechanism at work, it operates mainly via human capital deterioration. Somewhat simplified, this interpretation says that, due to the high unemployment caused by the previous economic crisis, the productive potential of human capital becomes reduced and less productive than before. It operates either through the devastation of previously accumulated skills and knowledge or through the reduction or elimination of the 'learning by doing' process of skill accumulation which is lost when young people do not have a job (Gleaser, 2014; Teulings and Baldwin, 2014, for example). 
Finally, the last explanation is the one offered by Rogoff (2015) and some other authors (Borio, 2017; Koo, 2003, 2014) according to which this prolonged rate of growth retardation is a result of just another financial cycle, this time the mega financial cycle. Especially important is to consider the situation when previously blown bubble(s) burst. Quite naturally, when asset bubbles burst, everybody will try to return his loans. This is how the process of deleveraging begins. From the point of view of the individual agent, this is the only rational option. However, from the economy wide and social point of view, the effects of massive deleveraging are devastating. Due to everybody's effort to return their loans, the aggregate demand strongly shrinks and it produce a large decline of aggregate supply. Since deleveraging is not an instant process but takes some time, the decline of aggregate demand leads to a long term GDP growth decline. Richard Koo (2014) argues that the key feature of the 1929 crisis and the current 2008 crisis is "the bursting of a debt-financed asset bubble and that such 'balance sheet recessions' take a long time to recover from". Note, however, that this process would not be possible without movements on the supply and demand side or in the real economy. In other words, this interesting explanation should be integrated with the first two. Blowing of the bubble and the process of financialization after all occurred as a result of an effort to overcome problems related to the limitations on the demand side. The same applies to hysteresis hypothesis, which can also be easily integrated within the first two hypotheses framework.

5. Efforts towards making economic models of secular stagnation, which are a prerequisite for serious econometric research of this topic, are at the very early stage of development. The first effort in this direction was done by Eggertsson and Mehrotra (2014). In this first paper, the authors propose a simple overlapping generations New Keynesian model in which a permanent slump is possible without any self-correcting force that would lead toward natural employment. This model, unfortunately, can be applied only in the case of a closed economy. Recently, however, Eggertsson, Mehrotra, and Summers (2016) developed a model of secular stagnation for an open economy. ${ }^{1}$ The conditions of secular stagnation which, as we know, include low interest rates below target inflation, and sluggish output growth, according to authors, now characterize much of the global economy. In this paper they consider a simple two-country textbook model to examine how capital markets transmit secular stagnation and to study policy externalities across countries.

1 See also Eggertsson, G. B., Mehrotra, N. R., Singh, S. R., and Summers, L. H. (2015). 


\section{Supply side explanations}

1. According to this theory, in developed countries we are faced with a decline of long term potential growth rate. The decline of the growth rate can be a result of the decline of the slope of long term potential growth path and/or a result of a drop of the long term growth path. This, of course, can happen only as a consequence of decline of Solow-Romer factors of growth which can occur either as a result of (i) a decline of the growth of the primary productive inputs (capital and labour) or as a result of a decline of (ii) factors that determine efficiency of productive inputs (known together as Total Factor Productivity - TFP). As is well known, in Solow's old theory drop of a growth path can occur only as a result of a decline in growth of primary inputs, which will result in a decline in medium term growth rates. A decline in the long term rate of growth can occur only as a result of a decline in the rate of growth of TFP. On the other hand, according to Romer and other versions of the new growth theory, a decline in the long term rate of growth can occur either due to decline in TFP growth rate or due to a decline in the rate of growth of primary productive inputs.

Especially interesting in this school of thinking is its strong insistence on a decline of factors that determine efficiency of productive inputs - TFP rate of growth decline. The hypothesis of TFP decline is even more surprising keeping in mind the fact that TFP is determined by an increase of different forms of knowledge which can enter the productive process either via innovation and improvement of equipment or via improvement of labour skill and the accumulation of human capital in general. Not only is it true that the prevailing evidence does not support this claim, but, contrary to that, we can indeed say that the most important characteristics of the era in which we live is the enormous increase of innovations and all forms of knowledge.

Robert Gordon (2012) was the first to stress the importance of this factor in explaining the current stagnation in the US economy. He claims that all the important innovations, like electricity, the internal combustion engine, indoor plumbing and others, are already discovered and for that reason we cannot expect the growth rate of TFP to be as large as it used to be during several decades of the 20 th century. He later clarified his view by insisting that he was not talking about TFP growth rate deceleration but about its return to previous historical lower level (Gordon, 2014a, 2014b, 2014c, 2015). In that respect, he points to the fact that after isolating the impact of other factors, three decades before 1930 and four decades after 1980, TFP growth rate was $0.5 \%$ annually. In the period between 1930 and 1980 it was three times higher, 1.5 percent annually. 
Gordon's idea about the TFP growth rate decline or a return to its historic low level has been severely criticized by a great number of authors. Mokyr (2014), Glaeser (2014), and Craft (2014) cast serious doubt on Gordon's projections that imply low level of TFP growth rate. Mokyr (2014) claims that IT, biotechnology, nanotechnology, and new materials are going to change the world dramatically. More importantly, he and the other authors also insist that the contribution of IT to our wellbeing is not evident from the productivity statistics because the way we measure GPD, labour productivity, and TFP growth is good for the "wheatand-steel economy" and not for the new "gadget-economy". It works relatively properly when pure quantities matter, but it does not make sense for measuring the effect of the IT revolution. Very often, despite the efforts of statisticians to amend their methodology, it does not make sense when the main aim and result of innovative activity is the improvement of the quality of products. This is exactly what has been happening within computer and other IT industries in the past several decades. The short framework for critical consideration of this sort of critique of Gordon's approach as well as for the critical approach to Gordon's explanation is given in the following paragraphs.

2. It is well known that in order to properly measure all benefits of innovation we should take into account not only an increase of producer surplus, but also the consumer surplus increase generated by the introduction of new products or processes. Stream of total benefits calculated as a sum of both producer and consumer surplus, which is known as social surplus, should be compared to the stream of the social cost of the respected innovation to get a proper measure of the effectiveness of certain innovations. This is how we get appropriate measure of the (internal) rate of return on investments in innovations and in $\mathrm{R} \& \mathrm{D}$ in general. The above critique of Gordon's idea of TFP deceleration is consequently based on two beliefs. First, the national account and macroeconomic approach in measuring effectiveness of IT innovations does not take into account consumer surplus. It basically captures just the effect of increase of producer surplus. Second, modern IT and other innovations are predominantly given in the form of consumer surplus increase. Smart phones, for example, offer according to this argument a lot of services to their owners that have not been capitalized in the price paid for them. Very often, consumer surplus is the only part of social surplus which is generated by the innovation in question. In such circumstances, according to this critique, not only are the measures of effectiveness of innovations underestimated, but the measure of GDP itself becomes problematic and can cast serious doubts on the very idea of GDP stagnation. 
The idea that consumer surplus increase dominates in modern innovation is interesting and very appealing, but it requires further empirical investigation to be accepted. At the theoretical level, it is well very known that every innovation, whether in the form of new or improved products or processes, generate streams of benefits, first to initial producers (innovators), then to their buyers that may be new producers in some downstream industries, and finally, to consumers as final users. The stream of benefits captured by the first two groups of agents is known as a producer surplus, while the stream of benefits captured by the last agent is known as a consumer surplus. Together they make social surplus. The division of social surplus between different producers and consumers is determined by the shape of the respected demand and supply function that connect different agents or, more precisely, by the price elasticity of the respected demand and supply functions. The fact that macroeconomic measurement of the contribution of innovation is smaller than its real contribution, measured with social surplus, is an old and well-known story. The new thing in the above argument is claim that this underestimation is much stronger in the case of IT and modern innovations than what it used to be in previous decades. Obviously, to prove that modern technological progress manifests mainly via an increase of quality of final products and the consequent consumer surplus increase requires some serious empirical investigations. The same applies to the Gordon's claim regarding the return of technological progress to old lower historical level.

3. The situation with innovative activities and R\&D activities which generate IT and other modern innovations is, however, much more complicated and requires, first, our better understanding of the consequences of IT innovations - first for the IT industry itself and, then, for other downstream industries that use these innovations. R\&D and other innovative activities are rarely organized as independent companies or business entities. For natural and very much known reason, they are predominantly organized as a part of big companies and are supposed to service companies to which they belong. As we already explained, the positive effects of innovations measured by social surplus are then divided between producers who appropriate producer surplus, and consumers who appropriate consumer surplus. In order to maximize his earning, an innovator needs to design a new product (or improve an old one) in a way which will first make the cost of producing a new product as low as possible and, second, will be truly useful and, in that way, (possibly) sell that products for as high a price as possible. So, profit maximization in innovative activity is made up of two tasks: the first task is to make the cost of producing the new (or improved old) product as low as 
possible, and the second task is to make the selling prices of new product as high as possible by making them as useful as possible. ${ }^{2}$

As far as the cost minimization side is regarded, it can be said that the aim of an innovator is to reduce the usage of all possible inputs necessary for the production of new or improved old product. Especially important is the cost savings of those inputs that are particularly expensive. As a matter of fact, total costs of new / improved product can be, and very often are, reduced by substituting some very expensive inputs with relatively cheap ones. Looking at the aggregate level, it can be noticed that, from the historical perspective, labour has been the most expensive input and that, simultaneously, labour input prices have experienced a very high increase. For the sake of illustration, note that until a couple of decades ago, the share of labour income in GDP used to be about 70\% to 75\% in developed countries, and that increase in wages used to be the same as the increase of labour productivity and total factor productivity. This is why economic growth has been followed by the permanent substitution of expensive labour with relatively less expensive capital.

The above described process determines also the share of certain inputs/costs in the price of particular product as well as the share of primary inputs, labour and capital, in GDP. Interestingly enough, until recently, the constancy of primary factor shares, which assumes unit elasticity of the substitution between labour and capital, has been regarded as one of the most important and unquestionable stylized facts of economic growth. The Cobb-Douglas (1928) aggregate production function and the Solow Growth Model(s) (Solow, 1956, 1957, 1959a, 1959b, 1962a, 1962b) satisfy this assumption and this is why this model of growth has been so frequently used in empirical as well as theoretical research. However, the Cobb-Douglas aggregate production function is not the only one which satisfies the assumption of the constancy of factor shares. The same result can be provided with a zero-elasticity-of-substitution production function (Leontief production function), once it is assumed that technological progress shifts the kinked isoquant of new vintages of capital in a way where the capital-labour ratio increases at the same rate at which the expected wage-profit ratio increases. This guaran-

2 To our knowledge Edward Mansfield was the first who made series of detailed cost-benefit analyses of efficiency of investment in different innovations from the micro economic perspective (Edward Mansfield, 1965, 1968a, 1968b, 1971, 1977, 1982, 1984). Especially important in this kind of research is the decomposition of social surplus of different innovations into consumer surplus and producer surplus contributions. 
tees a constancy of capital to labour earnings ratio which guarantees constancy of capital and labour shares in GDP. ${ }^{3}$

In growth model which assumes a kinked isoquant, the possibilities of factors substitution exist only before and during investments in R\&D are undertaken, and not before investment in new vintage of physical capital or after investment in new vintage have been done. A growth model based on such an aggregate production function could be regarded as a kind of putty-clay-clay model. It describes what we have in reality in a much better way than the models based on the CD function do. Simply speaking, it is unacceptable to assume that economic agents conduct their R\&D and inventive activities in order to "discover" all possible factor combinations that are associated with a certain level of production. It would be prohibitively costly to do something like that and it is something that the CD function implicitly assumes by allowing factor substitution ex ante and ex post investment in new vintages of capital. Being a rational ignorant, an economic agent makes his decisions based on factor combinations during the R\&D process, following expectations regarding future wages and other factor prices.

The above analysis applies at the microeconomic level as well, except that in that case we are dealing not only with cost minimization of primary input, capital and labour, but with all intermediary inputs as well. In this respect, the most interesting things with computers happened not in the 1950s when they were discovered and used for the first time in the form of the main-frame-computers, but instead in 1973 when the first microprocessor was discovered. Being based on cheap materials, like silicon component present in sand and similar almost costless materials, this innovation made possible the production of a new generation of very cheap computers, so cheap that within a couple of decades they have reached almost every household and every single office. So, by enormously reducing the cost of production of computers, this innovation, and not the discovery of computers themselves, has increased the affordability and speed of computer diffusion to a previously unbelievable level.

4. Take a look now at the other side of profit maximization regarding innovative activity - that is the usefulness of a new product and its selling price. More useful

\footnotetext{
3 Piketty (2014) in his celebrated book questioned, among other things, even the empirical validity of the constant factor share assumption. By presenting data for five countries in the 19th century, he showed that in the so called old belle époque period after the industrial revolution in Europe and before WWI, capital share was much larger than what it used to be during the dominant part of the $20^{\text {th }}$ century. Interestingly, in the period after the modern technological revolution and before the most recent economic crisis, developed countries again experienced a significant increase of capital incomes share in GDP, a jump from $30 \%$ to about $40 \%$.
} 
new or improved old products are for customers or other downstream producers, their selling price should be higher. As far as computers are regarded, it can be said that, by solving the problem of overheating which characterized earlier transistor based computers, innovation from 1973 increased the usefulness of the new generations of computers in an even more dramatic capacity. Especially interesting and important is to re-examine the usefulness of computers for other producers and downstream industries. The microprocessor as an innovation occurred in 1973, the first microcomputers (Sinclair 48, Commodore 64) by the beginning of the 1980s, and just a couple of years later the IBM's first PC computer with only $16 \mathrm{~KB}$ of memory, then a generation of PC - XT 286 and AT 286, which was followed by the AT 386, AT 486, Pentium, and so on. Some rough estimates made during the mid-1980s revealed that one PC computer of this generation was able to substitute 8 people working when it came to producing and processing information. At the same time, numerous studies have discovered that in developed countries at that time only 2 out of 10 workers used to work at executive activities, while 8 out of 10 people used to work on processing information either at a hierarchical structure of companies or in the public sector and various government organizations. It was obvious that a great substitution of labour with computers was ahead of us. It is not surprising that Jeremy Rifkin's book from 1995 titled The End of Work: The Decline of the Global Labour Force and the Dawn of the Post-Market Era became a bestseller at that time. Note, however, that, first, it was not possible to substitute all information processing activities. Only the routine labour activities could have been substituted with computers. In the next decades, however, due to the development of artificial intelligence and consequent ongoing sophistication of robots, the non-routine labour activities will also be substituted by machine. Second, it was natural to expect that, due to the developments within electronic and software industries, a new kind of jobs will appear and spread, and in that way mitigate for a while a possible problem of unemployment. Finally, since the cost of producing information became extremely low, companies and other organizations increased demand for information for business decision making, which in that way further slowdown the process of possible labour substitution. ${ }^{4}$

The fact that one computer with an operator could substitute eight employees working on producing and processing information was the testament to the

4 Indicative and illustrative are results of Eden and Gaggl $(2014,2016)$ with their recent research according to which income share of routine labour activities in the USA dropped from 38 percent in 1979 to 23 percent in 2012. This 15-percentage point drop is significant indeed. It presents a decrease of share of about 40 percent in the entire period or 2.8 percent annually. Also, not less important is the finding according to which a decline of labour share in GDP is mainly the result of a decline of routine labour share in GDP. 
power and usefulness of the new generation of computers at that time. On the other hand, the fact that 8 out of 10 employees at that time used to work on data processing was a testament to the magnitude of reserves necessary for this form of labour substitution. Also, with the use of these new computers, a new possibility for the reduction of costs in downstream industries, which were producing all sorts of products, became possible. That number - $80 \%$ - is such a huge reserve that it sounds almost unbelievable. To make this figure believable, some historical clarifications will be needed. Technological progress, since the beginning of the industrial revolution until now, has been described as a permanent differentiation of technological activities and the consequently permanent deeper and deeper division of labour. It is well known that this differentiation of technological activities has been followed by the permanent differentiation, growth, and development of the market. The market, as a way of coordinating different economic activities, was a prerequisite for technological progress. Technological progress itself equally contributed to the invention and diffusion of a host of new market institutions. What is less known to economists and very much known to business historians is the fact that the market was not alone in regard to coordinating new technological complexities (Alfred Chandler, 1977). Apart from the market, it was necessary to develop and change hierarchical structures of companies themselves. As a result, apart from market development, what we have experienced is that more and more differentiated activities get closed within companies and coordinated by hierarchical structure. This is how and why the number of levels of hierarchical structures and the number of employees within hierarchical structures started to increase. Needless to say, almost all working activities within hierarchical structures were devoted to producing and processing information necessary for decision making and coordinating transactions within companies. Note that the allocation of transactions between the market and the hierarchical structures was always a private decision, and that the mere fact that some activities have been coordinated within hierarchies witness about certain market failures when it came to coordinating different transactions. On the other hand, some other very severe market failures have been overcome by public decisions and the development of a public sector which itself also assumes the development of a strong hierarchy.

This is summary approximate and short explanation showing how the number of employees dealing with information processing reached such high levels - levels of about $80 \%$. So, technological progress until the 1990 s was followed not only by capital labour substitution, but also by the substitution of executive labour with labour from organized hierarchies. Obviously, once the new generation of affordable and cheap computers appeared, this attacked the tower of employees in the hierarchical structures, which were a bastion of labour and knowledge intensive activities. As a 
consequence, the 1990s brought about numerous social innovations that occurred as a result of the possibilities offered by computers. The "flattering" of organizations was followed by a dramatic reduction in the number of levels within the hierarchies. Outsourcing, which had very often been managed like management-buy-out or employee-buy-out, contributed further to the weakening of hierarchical structures. Reengineering was a much more complex form of organizational restructuring. The cause of all this restructuring was, without a doubt, the computer and IT revolution, while the end result of all this was a weakening of hierarchies and the substitution of employees within hierarchies with computers. ${ }^{5}$

5. Several important conclusions follow directly or can be derived from the above considerations. First, it can with great certainty be concluded that Gordon's insistence on the decline of TFP rate of growth or to its return to low historical level is very debatable and weakly evidenced. The idea that most important innovations are already discovered is in sharp contrast with the prevailing and obvious evidence. Obvious decline of TFP growth can equally be explained with a drop of aggregate demand. Also debatable is, in that respect, his idea that while old innovations used to have very strong effects on all possible industries, new IT innovations do not have such widespread impact. This idea is simply wrong: we know that computers alone have destroyed hierarchical structures as we know them and, in that way, initiated the substitution of labour with capital never seen before in all industries.

Second, it is equally obvious that authors who attacked Gordon's position by pointing to the fact that new IT and digital innovations have had a predominant impact on the increase of consumer surplus are also wrong. More precisely, despite the fact that the increase in consumer surplus is large, there is no reason to believe that the share of consumer surplus in the total social surplus is larger in the new IT generation than it was in the older generation of innovations.

Third, the IT revolution is characterized with a dramatic decrease in the prices of all new IT products. This is especially obvious in the case of computers. Despite the fact that the usefulness of new generations of computers increases enormously and should therefore increase their price, they have actually strongly decreased due to the fact that the cost of their production decreases even more dramatically than the increase in their quality. Since the beginning of 1990s, the share of computers and other IT product in total investment increased significantly, and the relative price of investment decreased significantly as well. In other words, it became pos-

\footnotetext{
5 Above short description of "rise and fall" of business hierarchy is, apart from the Chandler's description (1977), based on works and ideas of Ronald Coase (1937), Herbert Simon (1947), Oliver Williamson (1985), and on the most recent works of Lamoreaux, Raff, and Temin (2002), and Lazonick (2016).
} 
sible to buy the same number of machines (computers) for a much smaller amount of money. This decrease of investment relative price was an important reason for a decrease of investment and the consequent decline of economic activity. But this impact of technological progress on growth slowdown operates via the demand side of the story and will be discussed in the next two sections.

Forth, an enormous substitution of labour, caused by computers and other new IT products, has been followed by a decrease of the wage bill (from $70 \%$ to $60 \%$ of GDP) and a consequent increase of capital income share (from $30 \%$ to $40 \%$ of GDP). It also contributed to increase of income inequalities to unprecedented levels. All this has further been followed by a relative decrease of private consumption and an increase in saving. This has inevitably led to a relative decrease of aggregate demand and a consequent decline of the level of economic activity. But this impact of technological progress on growth decline also operates via the aggregate demand side of the story and will be discussed in the following sections.

\section{Demand side explanations}

1. An effective demand side explanation insists that the current growth slowdown in developed countries is a result of the persistent deviation of actual growth from potential growth that occurs as a result of the persistent limitation on the side of aggregate demand. According to this explanation, the Say's law does not apply even in the long term. In other words, even in the long term, it is not true that every level of aggregate supply creates its own aggregate demand. Quite the contrary, every aggregate demand creates and has its own aggregate supply. Let's now examine how this may happen, even in the long run - how aggregate demand can be smaller than aggregate supply.

Since aggregate demand is made up of individual consumption (C), public expenditure (G), domestic investment (I), and net export (NX), damages may occur due to unusual behaviour of any of its parts. In this particular case, like in many others, the problem is with relatively low level of investment expenditure. More precisely, the problem occurs due to the discrepancy between saving and investment. As we know, disposable income is divided into individual consumption and saving. In normal circumstances, saving is supposed to be transformed into domestic investment. If domestic saving is higher than domestic investment then, again only in normal circumstances, the surplus saving is going to be transformed into investment abroad and this will be manifested as an increase in net export and current account. This saving/investment and, in that way, the aggregate supply/aggregate demand adjustment mechanism assumes adequate 
dynamics of the unit labour cost and the consequent real exchange rate and competitiveness of the respected economy at the world market. Unit labour cost and real exchange rate dynamics are, on the other hand, determined with the productivity and wages dynamics in the respected country.

If the unit labour cost and real exchange rate dynamics do not satisfy equilibrium conditions, then another adjustment mechanism is supposed to manage saving/investment and demand/supply imbalances. Imbalances expressed here, as already explained, as excess savings over investments and the consequent excess aggregate supply over aggregate demand, are supposed to be solved by the adjustment of interest rates in the market of loanable funds. Obviously, the above situation assumes an adjustment process that is followed by a decrease of real interest rates. A decrease of the real interest rate destimulates savings and, therefore, should be followed with a decrease of saving. On the other hand, a decrease of the interest rate, by increasing the number of sustainable projects, should be followed by an increase in investment in the market of loanable funds. At a certain point, saving becomes equal to investment and aggregate demand becomes equal to aggregate supply. At the same time, the level of economic activity and unemployment reach their "natural" levels. (At the same time, a decrease in interest rate helps adjustments that work via the above described exchange rate and net export mechanisms.) The level of real interest rate which guarantees this kind of macroeconomic equilibrium is known as the "natural" interest rate. This term was used for the first time by a Swedish economist Knut Wicksell (1851-1926). Most economists still use this term.

Of course, the prerequisite for the above described process of macroeconomic adjustment is a full flexibility of interest rate. It may happen, however, that the saving surplus over investment is so high that the only way to attain macroeconomic equilibrium is by adjusting the natural interest rate to be negative. However, according to many researchers, this management is very difficult and, even when possible, very problematic. The problem we have here is that in the modern economy, due to currency substitution, short term safe interest rates cannot fall below zero or, more precisely, below the level of risk premium. We are here encountered with what is known as the Zero Lower Bound (ZLB) interest rate. So, the nominal interest rate is not flexible and cannot fall below zero. In these circumstances where it is not so easy to reach the natural interest rate, it is very difficult to attain the previously described macroeconomic stability. The consequence is a persistent excess of saving over investment and a consequent limitation on the side of aggregate demand. This limitation leads to a persistent decline of the actual GDP below its potential level. The final consequence is a long term decline in economic growth. The name of this kind of decline is secular stagnation. 
Laurence Summers recently (2013, 2014a, 2014b, 2015, 2016) initiated a revival of this discussion on the secular stagnation hypothesis. Note, however, that it was Alvin Hansen (1939) who first developed this hypothesis in 1938, a couple of years before WWII and several years after the beginning of The Great Depression. While the causes of secular stagnation at that time, according to Hansen, used to relate to the growth slowdown of the population and labour force, recent secular stagnation is explained, apart from population movements, by some other more important factors. The macroeconomic narrative in both cases, however, focuses on the problem of negative natural interest rates. World War II and the consequent huge public expenditure explain how GDP in the U.S. economy doubled in the short period from 1939 to 1945 . On top of that, after the war, all western economies experienced a dynamic increase of population due to the dramatic increase of birth rates in 1945-1960 so, as Hansen pointed out, the main reason for stagnation disappeared. This is how the secular stagnation hypothesis vanished from our lives and the economic literature for more than seven decades.

In the last couple of years, due to the Summers's (2013) speech at the IMF annual conference, the hypothesis of secular stagnation was put back on the table in developed countries. Among proponents of this hypothesis, a consensus is being reached on three issues. First, all of them agree that a negative real interest rate is needed to equate saving and investment and, at the same time, to reach a full natural employment and potential GDP. Second, there is also an agreement that it is difficult to reach full employment and negative natural interest rates with low inflation and ZLB (Zero Lower Bound) nominal interest rates, a situation that very much resembles the actual current state in developed countries. Finally, there is also a consensus about the claim that if secular stagnation is "real", than the whole macroeconomics has to be reinvented.

2. The only way to make the real interest rate negative is to abandon the policy of low level of inflation ( $1.5 \%$ to $2 \%$ in the past 35 years) and to allow for a much higher rate of inflation (above 4\%). If the rate of inflation is higher than the nominal interest rate, then the real interest rate will be negative. Apart from that, of course, according to this explanation, the nominal interest rate should be at the lowest possible level. With a lower nominal interest rate it will be possible to reach a negative real interest rate with a lower rate of inflation. Note, however, that the very low level of real interest rate can itself cause significant financial instability even without any inflation. Summers (2014a) insists that a low level of interest rate could promote financial instability in several ways. First, it promotes risk taking as investors reach for yield. Second, it promotes irresponsible landing as coupon obligations become low and easy to meet. Finally, it stimulates agents to make Ponzi financial structures. It is more attractive to make such structure 
since interest rates look low compared to the expected growth rates. So, a negative real interest rate should be reached by searching for optimal levels of inflation and a level of nominal interest rate.

According to Summers (2013, 2014a, 2014b, 2015, 2016), long term growth stagnation is, in fact, a problem that has been present for a long time but that has been masked by unsustainable finances. If we take a closer look at the U.S. economy, it can be noticed that in the 2002-2007 pre-crisis period, the economy experienced very decent growth. At the same time, however, we witnessed a strong erosion of the credit standard (NINJA loans, No Income - No Jobs Loans, for example), the biggest housing bubble in the recorded history of the USA, an emergence of a budget deficit, lax regulatory and monetary policy, and many other signs of unsustainable finance. Without these financial failures, however, it would not be possible to have such a strong growth seen at the time and to get out of the 20012002 Dot-Com crisis.

Similarly, the unprecedented growth of the U.S. economy in 1990s was only partially a consequence of the new industrial revolution. To a large extent, it was a result of a huge bubble in the capital market, which was created not only by unrealistic market optimism, and attributable to technological revolution, but also created by a huge increase of baby-boomers retirement savings, and, even to a greater extent, created by a large stream of savings coming from emerging countries to the USA. Monetary policy at that time was mainly determined by the above movements and changes. For example, from 1993 to 2001, the annual growth rate of the DJ index was about 18\%, meaning that in 1993-2001, the DJ index doubled twice and increased from around 3000 to 12000 . At the same time, inflation was at a decent level of about $1.5 \%$ to $2 \%$. The end result of this was a high discrepancy between goods and property prices. Property prices increased much higher than prices of goods and services. After all, this growth ended in 2001 with the DotCom crisis which was so powerful that the DJ index dropped by more than $25 \%$. The recovery, as we saw, was possible only by engaging in new financial failures.

The same phenomenon, an inability for the economy to create strong long term growth without unsustainable finance practices, is characteristic of the European economy as well. The situation in Europe is, unfortunately, much more complicated and that is why this cannot be seen as easy on one hand, and also why it is more difficult to make the financial system more unsustainable, on the other hand. Nevertheless, it is obvious that strong export and export-led growth in Western and Northern Europe economies would not be possible without unsustainable ways of financing them. Connected with that is the growth of the European periphery which would be impossible without the availability of inappropriately cheap loans. 
So, it indeed seems that in the absence of unsustainable financing in developed countries it is not possible to reach a decent growth rate. The probable explanation of this phenomenon seems to be the long term presence of secular stagna-

tion. The government's policy

\section{Graph 4: World Average Real Interest Rate}

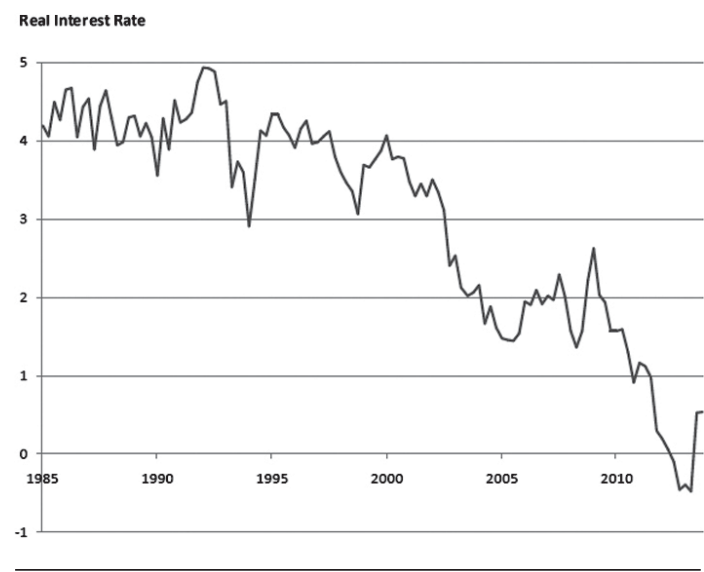

Source: Mervyn King, "Measuring the World Interest Rate".

Taken from Summers (2014a)

Graph 5: Natural Rate of Interest in USA

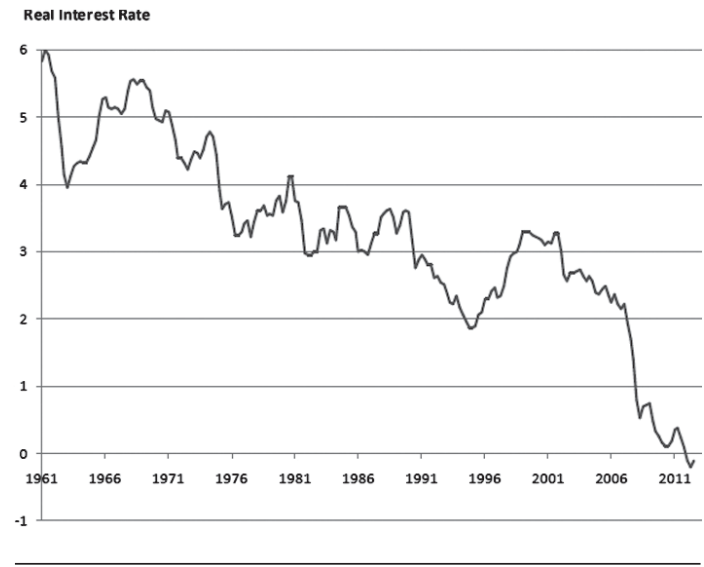

Sources: Thomas Laubach and John Williams: "Measuring the Natural Rate of Interest". Taken from Summers (2014a) dilemma in these circumstances for developed countries seems to be the choice between a sluggish growth without a bubble and a strong growth with a bubble (Summers, 2014a).

3. Interestingly enough, and quite in accordance with the previous considerations, it is noticeable that since the beginning of the new era of globalization, known as hyper-globalization, the real interest rate has declined substantially. From the Graph 4, it can be seen that the world real interest rate declined from the beginning of the 1980s to the mid-1990s mildly but significantly (from about $4 \%$ to about 3,5\%). After that and especially after 2000 , it decreased dramatically and reached below zero levels at certain points.

The same trend can be noticed in the Graph 5, which refers to the natural rate of interest in the U.S. economy. As can be seen, the natural interest rate in the case of the USA declined for a much longer period. The decline here started at the beginning of the 1960s and at the very end also reached below zero levels at certain points. 
Finally, the Graph 6, presents the movement of the real interest rate in the world, advanced, and emerging economies from 1980 until 2015. The data there are very insightful and in accordance with our considerations and the findings presented in previous graphs as well.

So, historical data seems to suggest that in the last several decades, economic growth has been followed with a decline of real and natural interest rates. Also, it seems that this growth would not have been possible without the decline of interest rates and the consequent fall into the zone of financial instability. This is an interesting and important finding indeed. ${ }^{6}$
Graph 6: Real interest rate in world, advanced and emerging economies

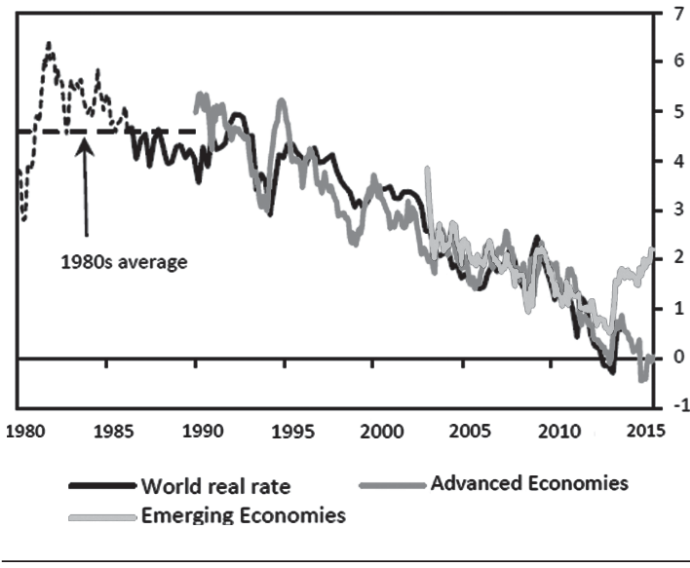

Source: King and Low (2014), Consensus Economics, IMF.

Taken from Rachel and Smith (2015).

\section{Causes of demand slowdown: circular and cumulative causation}

1. The effort to unveil factors behind the aggregate demand limitations to economic growth inevitably brings us again to the supply side dynamics and particularly to the innovative processes in the last couple of decades as being the main causes of aggregate demand growth path decline. Clues have already been given in the analysis of the supply side explanations of stagnation. The impact of those innovations have been so strong that very often, despite their enormous positive effects, societies have not been able to absorb them in a proper way and, as a consequence, instead of acting as "creative destruction" they acted more like "destructive creation". ' So, limitations on the demand side that are caused by

6 As far as world real interest rate movement is concerned, very interesting effort is that made by Rachel and Smith (2015) to decompose a decline of real interest rate on contribution of different factors that caused that decline.

7 John Komlos (2016a) in his analysis considers and tries to separate creative from destructive parts of innovations effect. 
the nature of the supply side innovative processes have an indirect effect on the supply side movement itself, and so on. There is no doubt that what we see here is a circular and cumulative causation and the interaction between aggregate demand and aggregate supply.

In the third section of the paper, we already described the main characteristics of the IT revolution in order to explore the possibility that ongoing stagnation is a result of the Solow-Romer factors decline and the consequent growth slowdown of potential growth rate. The conclusions reached there will now be of a crucial help in explaining the impact of the IT revolution on the persistent decline of aggregate demand and the consequent secular stagnation. This will be of great help later on when we turn to the explanation of globalization contribution to secular stagnation. It will be seen that the impact of globalization on secular stagnation is not only similar to that of the impact of innovations, but also that they both belong to the same sort of explanation. As far as the impact of the IT revolution is concerned, it is possible to talk about two channels through which it has influenced the magnitude and structure of aggregate demand.

1.1. First, it had already been extensively explained how, in the last three decades, the IT revolution has led to an enormous substitution of labour with machines within hierarchical structures for all companies and similar organizations. As a result, organization of companies as well as industrial organization have changed dramatically. Hierarchical structures, which had been a bastion of workers employed in producing and processing information, have been smashed and destroyed by the IT revolution. A huge pressure on the labour market has been made in that way. Such pressure on the labour market has been followed by a relative decline in the rate of growth for employment. It was very often followed with a decline in relative wage levels and, almost always, the wage increase was smaller than the increase of labour productivity and the total factor productivity. As a consequence, it has been followed by a decrease of the wage bill (from $70 \%$ to $60 \%$ of GDP) and the consequent increase of capital income share (from $30 \%$ to $40 \%$ of GDP).

Such pressure on the labour market also contributed to an increase of inequalities among employees. Especially noticeable is the increase of college graduates' salaries relative to the salaries of other employees. The issue of what causes the increase of graduate wage premiums is still controversial. One theory insists that modern technology is characterized by capital skill complementarity, meaning that once we start using new technology we need more skilful workers (Krusell at al., 1997), which increases the demand for college graduates and decreases the relative demand for less skilful workers. An alternative theory insist that globali- 
zation reallocates all labour intensive industries from developed to less developed countries and in that way reduces the relative demand and salaries for less skilled labour in developed countries. Finally, the last theory points to the importance of retardation of trade unions and the consequent weakening of workers bargaining power. The approach adopted here claims that there is no reason for polemic between the proponents of these theories since it is obvious that all these factors, in fact, play an equally important role in the increasing inequalities within modern developed countries.

Obviously, both the increase of capital share and the increase of inequality among employees, which are mainly determined by changes in technology, resulted in income inequalities that have not been seen in the statistical history of the developed world. These topics have been discussed so much recently that now everybody knows that the $1 \%$ of the richest in the USA hold $40 \%$ of the wealth and about $20 \%$ of the annual income. Interesting is also a less known fact that $80 \%$ of the USA population appropriates just $20 \%$ of the country's annual income, implying that $80 \%$ on average of the American population have a standard of living on par with the average citizen of the Western Balkan. A lot of good analysis and books have been written so far on this topic: Stiglitz (2012); Piketty (2014); Milanovic (2016), and many others. From a dynamic perspective, it is interesting that, according to John Komlos' (2016) research, since 1979 until 2011, only 20\% of the richest families in the USA significantly improved their average income per family as well as family welfare. The first four quintiles ( $80 \%$ of families), on the other hand, actually experienced only a negligible increase of income per family and a decrease of family welfare. This, better than any other data, shows how fast and how strong the increase of inequality has been in the USA.

One of the most important consequences of this increase of inequality was a decline of the aggregate propensity to consume and an increase of the aggregate propensity to save. This is a result of the fact that less affluent families have a high propensity to consume and a small propensity to save, while rich families, on the other hand, have a low propensity to consume and a high propensity to save. Since almost the entire increase of income in the USA after 1979 has been appropriated by $20 \%$ of the richest families, it is natural to expect an increase of the aggregate propensity to save. This increase of saving has led to a discrepancy between saving and investment, which, as we already explained, led to a persistent discrepancy between the limited aggregate demand and aggregate supply. Aggregate demand became the limit for further GDP growth. Being unable to transform these savings into investments (at home or abroad) has made the economy react with all sorts of bubbles. 
1.2. The second channel through which technological changes have had an impact on the reduction of aggregate demand was a dramatic decrease of the price of computers and all other new IT products. This is especially visible in the case of computers. As has been explained, despite the fact that the usefulness/effectiveness of this new generations of computers has increase enormously and that this should have generated an increase of prices, their prices in fact strongly decreased due to the fact that the cost of their production decreased even more dramatically than the increase of their quality. Since, the share of computers and other IT products in the total investment has increased significantly from the mid1980s and the beginning of 1990s, it makes sense that the relative price of all investment decreased significantly. Simply speaking, it became possible to buy the same number of machines for a much smaller amount of money.

So, the decrease of relative prices of investment was a very important reason for the decrease of the nominal value of investment and for the consequent decline of aggregate demand. This decline of aggregate demand was an important reason for the further broadening of the discrepancy between aggregate demand and aggregate supply. The smaller value of aggregate demand, on the other hand, caused a decline of economic activity. It is interesting that, when measured in current prices, the share of investment in aggregate demand decreased significantly. However, when measured in constant prices, the share of investment in aggregate demand did not decrease and, in some cases, it even increased. All this is a result of the peculiar decrease of the relative price of new IT products/machines. It is peculiar because it has not been a common occurrence in the history of technological progress that new machines which substitute labour end up becoming cheaper than the old machines. On the contrary, the most common case was an increase of the prices of new machines compared to the old ones. In such situations, the sufficient condition for the introduction of a new machine was that its price increase was smaller than (the present value of) the cost reduction due to labour substituted with those new machines. ${ }^{8}$

2. It was already noticed that the impact of globalization on secular stagnation is not only similar to that of technical innovations and technological progress, but that they belong to the same sort of causal explanation. To understand why, recall Schumpeter's (1947) views on innovations and especially his insistence that we should consider both social and technical innovations and that social innovations could have an even greater impact on economy and society than technologi-

\footnotetext{
8 Very interesting and comprehensive empirical research on causes and consequences of investment goods price decline is given by Gregory Thwaites (2015).
} 
cal ones. Social as well as technical innovation can bring a huge increase of profit as well as an increase of social surplus.

Social innovations, despite their enormous benefits, can also act in destructive ways. The switch from Breton Woods to Hyper-Globalization, for example, presents an innovation of such great impact that it can only be compared with the IT revolution. Keeping in mind that they both have huge power as well as destructive potential and the fact that they both occurred at about the same time, it is not surprising that in the end they acted as the "perfect storm". In that respect, the impact of Hyper-Globalization on secular stagnation can be regarded from an international trade perspective as well as from an international finance perspective.

2.1. Looking at the international trade side of the story, it can be said that the stronger liberalization of trade, which started sometime at the end of the 1970s and the beginning of the 1980s, has had an impact which is very similar to the impact of technological innovations. It is not surprising that economists very often regard the import of goods and services as an alternative technology that can be used in 'producing' some goods or services. Indeed, if foreign goods are cheaper than ones produced with 'domestic technology', then we are going to buy foreign goods. And vice versa, if some domestic product is cheaper than the one from the world market, we are going to export that good at higher world prices. Trade liberalization in fact makes all traded goods cheaper for those countries that are buying them and more expensive for countries that are selling them. In that way, trade liberalization increases the volume of international trade. However, apart from many large benefits, trade liberalization has contributed significantly to the current secular stagnation in developed countries. This contribution, just like in the case of technological progress, has been twofold.

First, in the beginning, trade liberalization led to an enormous reallocation of labour-intensive industries and later of all other industries from developed to developing countries, mainly in China and other Asian countries. The differences in the level of development and in the level of wages among different world regions and countries were very large at the beginning of trade liberalization. Consequently, differences in the prices of goods and services between developed countries on one side, and developing or less developed countries, on the other side, were enormous at the beginning of hyper-globalization. The space for world market arbitrage and for further commodification was unbelievably large at the beginning of liberalization. Once world market arbitrage began, we witnessed a development of a world market that was stronger than any we had seen in human history. 
As a result of the huge increase of import from China and other developing countries from Asia and the rest of the world, almost all developed countries experienced devastating deindustrialization. As a natural consequence, the number of employees decreased by a significant extent. Equally important is the fact that wage levels in developing countries have not followed labour productivity and total factor productivity movements. While technological innovations lead to a substitution of labour with machines, the liberalization of international trade in developed countries has meant a substitution of domestic labour with foreign labour, mainly labour from developing and less developed countries. This is how trade liberalization contributed to a decrease of the wage bill and to an increase of income inequalities. Income inequalities, on the other hand, contributed to an increase of the aggregate propensity to save and consequently to an increase in savings. This further augmented the discrepancy between saving and investment and led to a slower growth of aggregate demand which limited and reduced GDP growth of developed economies.

Second, from the perspective of developed countries, trade liberalization also meant that the import of cheaper products and services, which are a part of investment, has led to a decrease of the relative prices of investment. So, not only because of peculiar nature of the IT revolution, but also due to the decrease of imported investment prices which was initiated by the world market arbitrage, it became possible to buy the "same number of machine with less money". A decrease of investment prices, as already explained, further reduced the level of nominal investment and broadened the discrepancy between saving and investment. This additionally contributed to the shrinking of the growth rate of aggregate demand and, in that way, to limited economic activity and GDP growth rate.

2.2. Turning now to the international finance side of the story, it can be said that the most important impact in that respect is related to the so-called global saving glut phenomenon. Globalization, in fact, has contributed to savings in the USA and other developed countries to be even larger than what it would otherwise be. This was a result of an increase of capital flow from China and other emerging economies towards the USA and other developed countries. This capital flow is bit peculiar since we would expect capital to go from developed to developing countries. However, successful emerging economies first experienced a natural increase in demand for international currency reserves, predominantly of USD and EUR. Second, despite being successful, these countries were not able to find better investments than US T-bills and other government's or company's securities due to limited investment absorption capacity. In order to avoid interest rate increases, currency appreciation, and the consequent deterioration of domestic economy competitiveness, the monetary authority of the USA and other devel- 
oped countries very often opted for expansionary monetary policy (low interest rates). That's exactly what happened in the USA in 1990s.

The most important effect of the global impact on increased saving in the developed world, is the further broadening of the saving/investment discrepancy and the consequent slower growth of aggregate demand in developed countries. The slowdown of aggregate demand, on the other hand, caused the growth of GDP to decelerate as well. To get an idea about the possible size of that discrepancy, note that, according to Yanis Varoufakis (2015), about $80 \%$ of the world's free reserves were directed toward U.S. markets.

Even more interesting is a fact that in the case of the USA (and other developed economies) this also explains the fact that the market was not able to transform saving into investment (at home or abroad) and in that way resolve the problems associated with excess saving and a weak growth of aggregate demand. In fact, despite low interest rates, the U.S. economy has experienced a permanent trade and current account deficit since the end of the 1960s. No matter how much you reduce the interest rate, you will not be able to reach positive trade and current account if you also want to increase all sorts of spending by simply printing your money, which happens to be international money as well. So, the adjustment mechanism that goes via international economic relations was and is, in fact, suspended in the USA and other developed countries. In such circumstances, the only mechanism that operates is the one which goes via the interest rate's impact on the market of loanable funds. However, once we reduce the interest rate in order to stimulate growth, the side effects are all sorts of bubbles and other forms of financial instabilities.

3. We can conclude at the end that the current Great Recession, as well as the stagnation that followed in the developed world, cannot be understood solely by looking at the supply or demand side of things. Only with a proper understanding of the demand and supply interactions and the consequent acceptance of circular and cumulative causation, may we be able to fully understand what is really happening. This is the reason why we should be very careful in interpreting the theoretical consequences of different hypothesis and especially of empirical findings that might occur. For example, once we realize that aggregate demand might, for any of the reasons explained earlier, slow down and in that way limit the growth of aggregate supply, we should be aware that this slowdown of aggregate supply will not be of a short term nature. On the contrary, it will be of long term nature. A permanent decline of aggregate demand growth path will only manifest itself as short term in its nature maybe in the first couple of years. Only in the first couple of years will aggregate demand maybe happen to be smaller 
than the potential aggregate supply. After that, all economic agents will adjust levels and structures of all sorts of their investments and other expenditures to the levels and structures which are in accordance with the dropped aggregate demand. As a result, the economy will reach a growth path at which aggregate demand will be constantly equal to potential (or natural) aggregate supply. Note, however, that, despite the equality of the aggregate supply and aggregate demand, the slope of that growth path will be smaller than the potential. In other words, the potential growth rate of the economy will be higher than the actual growth rate. The actual GDP growth rate is limited by the peculiar slowdown of the aggregate demand growth path. Consequently, it will be very difficult to isolate the impact of the demand side from that of the supply side when it comes to growth rate stagnation. Or to quote Richard Gordon (2015): "In the end, secular stagnation is not about just demand or supply but also about the interaction between demand and supply."

Let us note at the end of this section that aggregate demand 's declining growth path is not only the result of the above discussed factors that occurred from innovation processes and supply side dynamics. Other factors can also have an impact on aggregate demand dynamics. In that respect, especially important is a decline of population and labour force that occurs as a result of demographic transition. Do not forget that in his explanation of secular stagnation, Alvin Hansen (1939), the first one to write about this issue, stressed the importance of demographic factors and he almost entirely relied on this factor. Many other authors, like Summers (2014a; 2014b) for example, also stressed the importance of population decline. The main idea here is that, as a result of the decline of population and labour force growth, the demand for new work declined. This means that the volume of investment may decline below the level of savings. Consequently, aggregate demand growth may decline as well. All this will naturally lead to a decrease of GDP growth. So, decline of population and labour force can have a twofold impact on growth. First, by being one of Solow-Romer's factors of growth, the decline of labour force has an impact on potential growth rate. Second, it has impact on growth due to a decline of aggregate demand that occurs via secular stagnation.

\section{Reoccurrence of dual economy and deindustrialization}

1. Long ago it has been noticed that, despite the strong technological changes that happened since the mid-1970s, TFP growth as well as labour productivity growth in the same period miraculously declined in almost all countries around the world and especially in developed countries. Salaries which, according to ba- 
sic stylized facts about growth, should have increased at the same (smaller) rate as TFP and labour productivities actually stagnated instead in almost all developed countries from 1973 until now. The above facts are very often used by some economists to question the importance of progress generated by new technology or, as already explained, to point out that progress here has quite a different nature from older innovations. This is very much a known productivity paradox and, since the end of the 1970s, a lot of different explanations have been offered to solve this puzzle. Accordingly, plenty of different causes of productivity growth retardation have been proposed, but the most important among them might be the reoccurrence of a dual economy and the fact that this reoccurrence is the result of revolutionary technological innovations and of Hyper-Globalization.

New technology, as already explained, is followed by enormous substitution of expensive labour, one that used to work within hierarchical structure, with cheap machines produced within electronic sectors. At the same time, HyperGlobalization, either via import from developing countries or via foreign direct investment, allowed enormous substitution of domestic labour, labour that used to work in manufacturing and industry in general, with the work of cheap labour from China and other Asian countries. As a result, the relative supply of labour in developed countries increased dramatically whilst the price of labour either declined or stagnated. With such a low price of labour, it was possible to develop and increase the share of some services characterized by labour intensity and low technological levels. So, both productivity and salaries in these services were very low and, as a consequence, it was possible to reallocate and increase the number of workers in these services. Note that we are talking about low productivity services and not about manufacturing or industry which is natural if we keep in mind that, due to globalization, developed countries have already been strongly deindustrialized.

Obviously, at the moment we can talk about two sectors in developed countries. More precisely we can talk about the reoccurrence of a dual economy in developed countries (Temin, 2015; Storm, 2017). One of them is the technologically advanced sector, characterized by high total factor and labour productivity and with a declining trend in the share of labour employed in it - currently about $30 \%$ in the USA, according to Temin (2015). Temin (2015) used the term FTE for this advanced sector in order to highlight the importance of Finance, Technology, and Electronics for this part of the economy. The remaining $70 \%$ of workers are employed at low level and stagnant productivity services. According to Storm (2017), the majority of workers in the USA had to find jobs in services-sector activities, mostly featuring below-average labour productivity growth: 18.9 million of workers are currently located in so-called EHS sector (education, health, 
and private social services), 16.2 million in PBS sector (professional and business services), 14.3 million in the so-called "other" sector (art, -entertainment, recreation, food services and other), 13.5 million in the public sector, and 5.7 million of worker in FIRE sector. Even when paid decently, jobs in the above sectors are often precarious or uncertain. It should be especially noticed that apart from income inequality, we should take a look at uncertainty redistribution as well. And obviously, in the last several decades, the greatest portion of risks has been redistributed to less advanced sectors and people employed there. That is why the most appropriate term for this class of the new poor is precariat, a word derived from the words 'proletariat' and 'precarious', which very properly describes the position of people working in this less advanced sector of the new dual economy.

Of course, salaries in the non-advanced sector are very low, but due to market arbitrage they are at a low level in the advanced sector as well. This explains the stagnation of salaries since the mid-1970s until today. However, this also explains the productivity paradox to a large extent as well. Technological progress indeed leads to a high increase of productivity, but only in the advanced sector. Now, due to labour substitution, the number of employees in this sector decreases, while the number of employees in the less advanced and low productivity sectors increases dramatically, causing in this way the growth of overall productivity to decelerate. $^{9}$

2. The first model of unbalanced growth with a dual economy, known as the model of growth with unlimited supply of labour, was developed in the early 1950s by Arthur Lewis (1954). Later it was mathematically formalized by Gustav Ranis and John Fei (Ranis and Fei, 1961; Fei and Ranis, 1964). The model, in fact, describes in a most appropriate way the beginning of the process of industrialization in the majority of now developed countries. At the same time, from the beginning of the 1950s this method had been mainly used in numerous discussions about strategies of development which were opened in the face of newly de-colonialized and liberated countries. Lewis became one of the most important scholars of that time period's prevailing school of theory of economic develop-

\footnotetext{
9 Apart from this, deceleration of productivity growth in the decade of the 1970s can to a certain extent be explained by the entrance of the Baby Boomers generation into the labour force as well as by the increasing participation of females of that generation in the labour force. Such a strong increase of labour supply has reduced salaries and in that way, due to low level of expected price of labour, reduced serious motivation for capital labour substitution i.e. for technological innovations. Indeed, one of the most important innovations of our time was the microprocessor and it happened in 1973. However, it was totally independent of any economic factors. It came from laboratories as a stochastic event, something that is so common for basic scientific research. Also, its first serious applications occurred by the beginning of the $1980 \mathrm{~s}$, one decade after the beginning of the productivity slowdown.
} 
ment, known at that time as the Theory of Strategies of Development which is now more commonly known as Old Economic Structuralism.

The main idea of this model is very simple. At the beginning of industrialization, there were two extremely different sectors. One is the industrial, commercial, urban or simply the "modern sector", while the other is agricultural, rural or simply the "traditional sector". Traditional sector is characterized with a relatively enormous number of people leaving from agriculture. At the same time, the marginal productivity of labour in the traditional sector is equal to zero for a great part of the labour allocated there. In the modern sector, on the other hand, the marginal productivity of labour is very high, mainly due to technological progress and to a relatively high level of capital per employee. Economies that happen to be in this situation are very often described as economies with unlimited supply of labour. If it is now possible to reallocate all labour with zero marginal productivity from traditional to modern sectors, than it is possible to dramatically increase GDP by simple reallocation and without any capital accumulation. This is the reason why many authors at that time used to call this model the "Model of Growth with Zero Accumulation." Once all labour with zero marginal productivity is reallocated from traditional to modern sector, this phase of growth is over and the country starts to grow just like in the models of balanced growth. Note that this reallocation phase of growth can last for several decades. Also, growth rates in that period are usually very high.

The most recent and most illustrative example for this dual economy model of growth is that of China. China's reforms started in 1978 and from that year until 2012 its rate of growth were almost 10 percent a year, meaning that China doubled its' GDP every seventh year at that time. Two other things are also important in the case of China. First, despite the decision to reduce the rate of growth to 7 percent, China still has not extracted all its labour with zero marginal productivity from the rural sector, meaning that the decision to slowdown the rate of growth is not the result of inability to use this model further (the rural population presents $40 \%$ of China population). Second, in the case of China, apart from the rural and modern sectors, a third sector should be added. This is the old, state owned sector, still not privatized and modernized. Apart from being used as a form of social policy (for this reason some economists use the term 'privatization without losers' for the China's experience in privatization), this sector presents an additional source of labour force for reallocation to modern sector.

Before turning to the issue of differences between old dual economies, like that of China, and new ones, like that of the USA and other developed countries, it is important to notice and point out the strong relationship between Chinese 
and American dualism in the era of Hyper-Globalization. Like any old dualism, Chinese dualism was based on the reallocation of labour from rural to modern sectors. However, Chinese growth has been, at the same time, led by export. The main products exported by China are those that belong to manufacture and industry in general, while the main export destination for Chinese goods has been the USA and other developed countries. In that respect, the trade liberalization that begins to accelerate by the beginning of the 1980s has been of crucial importance for the miracle of the Chinese economy. On the other hand, without new technologies and cheap import from developing countries like China, it would not be possible to develop the kind of dual economy which is prevailing now in the USA and other developed countries. A strong connection between the two dualisms is obvious. This is what contributed significantly to both dualisms becoming pretty stable and sustainable.

3. Obviously there are important differences between the old dual economy - the one that occurred at the beginning of industrialization, and the modern dual economy - the one that characterizes the period of IT revolution and deindustrialization in developed countries. The difference between the two dualisms is pretty clear. By shifting the labour with zero marginal productivity from rural sectors to urban sectors (and other sectors with high marginal productivities), the old dualism accelerated economic growth and initiated industrialization in the very beginning of economic growth of these countries with traditional economies. Due to that, economists very often say that agriculture presents an initial source of capital accumulation. Due to the nature of this phase of growth, the rates of growth are very high and allow the process of industrialization to spread very quickly. In the case of latecomers to the process of industrialization, this model of growth allows for a very fast convergence toward more developed countries assuming, of course, that there are no obstacles regarding geographical, institutional and international factors of growth.

On the other hand, new dualism occurs at a very high level of development and it operates like a kind of mechanism that slows down the rate of productivity growth. As already explained, it is a result of a strong labour substitution in the advanced sectors that, due to a strong pressure on labour markets, leads to stagnation and a decrease of wages and salaries. Once the expected price of labour becomes low, it becomes profitable to expand some less advanced and labour intensive services and to employ redundant labour in them. Due to the low productivity of these sectors, the overall productivity growth of the whole economy decreases as well. So this is how at high levels of development it happens that salaries stagnate whilst labour and total factor productivity rates of growth paradoxically start to decelerate. No doubt, the pattern of growth in the new dual econo- 
my is totally different from the one that characterizes the old dual economy. Both belong to non-equilibrium models of growth. One of them implies acceleration of growth, while the second one implies deceleration of growth.

4. Some might be inclined to claim that new dualism is, in fact, the appropriate model of growth by possibly suggesting the stabilization of growth and a consequent solution or mitigation to some problems that have been brought on by rapid growth (ecology, for example), as well as by suggesting the possibility of full employment. However, that growth stabilization is very problematic. The TFP and labour productivity growth slowdown is very bad at this stage of development because it implies a deceleration of technological progress. Low wages that dualism implies further de-stimulate labour substitution, either in traditional services that now employ redundant labour forces or for other activities that are still relatively labour intensive. The process of robotization would be extremely slow. Keeping in mind that the labour force is the scarcest resource, it would mean that technological progress would be very slow not only in the short term, but more dangerously in the long term. Note that other important forms of technological progress like energy or 'ecology' saving, for example, do not encounter this kind of obstacle.

This problem can be solved by some innovative aggregate demand management. In that respect, apart from classical monetary and fiscal policy (see Summers, 2015), Storm (2017) proposes the introduction of a minimal wage and its growth rate or minimal wage growth path policy. In proposing this policy, the author is mainly motivated by a desire to solve the problems of the limited aggregate demand growth path and the long term discrepancy between aggregate demand and possible aggregate supply. There is no doubt that this policy package can also be used to solve the problem of the above-described technological stagnation as well. What is not easy at all, however, is to overcome all possible obstacles on the road of political process aimed to introduce this kind of policy innovation. The same applies to energy, 'ecology', or any other form of resource saving or other forms of technological progress.

Note at the end that once the economy gets out of dualism and becomes monistic again, the minimal wage would be at a very high level and would not have any meaning as an instrument of social policy. It would be in fact a form of unconditional universal basic income aimed to keep aggregate demand and supply at an appropriate level. The magnitude of this would be so large that it can hardly even make any sense to use the term "labour market" in that case. The labour marked would de facto be suspended. Other markets will also change in their nature, keeping in mind that other forms of technological progress are going 
to bring us towards a "zero marginal cost society" (Rifkin, 2014). Aggregate demand management and other policies used nowadays, as well as the whole social organization, may in that circumstance appear to be too insufficient and weak to absorb the revolutionary technological changes that will obviously appear in the next couple of decades. Keeping in mind the current dynamics in the world of innovations, we now need a whole new method of social organization if we want to use and apply the expected stream of technological innovations. In other words, it seems that the main limitations of our society are on the side of social innovations and our consequent inability to absorb the enormous technological innovations that are in front of us.

\section{Conclusions}

Post-2007 growth stagnation of the world economy is, without a doubt, absolutely attributable to the drop of the growth path and the growth rate decline in the developed parts of the world.

As far as the causes of growth stagnation are regarded, it is obvious that this problem can only be understood within a circular and cumulative causation framework. Due to ZLB, it becomes very difficult to provide market adjustments of discrepancy between a high level of savings and a low level of investments which becomes the main cause of discrepancy between aggregate demand and aggregate supply and, in that way, the main source of decline of the demand growth path that has limited the growth of the economy. On the other hand, however, limitations on the demand side are almost entirely determined by dynamics on the supply side, especially by the dynamics of innovative processes. The strong substitution of labour with capital, an increase of inequality, and a decrease of investment prices are the main reasons for the saving-investment discrepancy, and mainly the consequence of the new IT revolution as well as of hyper-globalization which started at about same time, at the beginning of the 1980s.

One of the consequence of permanent labour substitution and deindustrialization of developed countries is the reoccurrence of a dual economy. Interestingly, this new dualism in the era of hyper-globalization operates together with old dualism. The example of China and the USA's coexistence as two dualisms is very illustrative in that respect. However, while the old dualism operates in a way which accelerates economic growth and allows for convergence, the new dualism is the main source of economic growth stagnation. This is how the puzzle of productivity paradox can be easily solved. On the other hand, the low price of labour in backward services within developed countries de-stimulates further in- 
novations which substitute labour with capital. This is the way in which the new dualism may act almost like a lock for further technological progress of this sort. Keeping this expected labour market weakness in mind and knowing that other technological innovations lead to a "zero marginal cost society" and consequent further weakening of other markets, it seems that we need an entirely new social organization in order to solve these serious problems. 


\section{References}

1. Blanchard, Oliver and Summers, Laurence (1986). "Hysteresis and the European Unemployment Problem”, NBER Macroeconomic Annual, Vol. 1, MIT Press, 15-90.

2. Borio, Claudio (2017). "Secular Stagnation or Financial Cycle Drag?". National Association for Business Economics, 33rd Economic Policy Conference 5-7 March 2017, Washington DC.

3. Chandler, Alfred (1977). The Visible Hand: The Managerial Revolution in American Business, Cambridge: Harvard University Press, 1977.

4. Coase, Ronald (1937). “The Nature of the Firm," Economica, 4, pp. 386-405.

5. Craft, Nicholas (2014). "Secular stagnation: US hypochondria, European disease?”, in Teulings, C. and Baldwin, R. (Editors) Secular Stagnation: Facts, Causes, and Cures, A VoxEU.org eBook, CEPR Press, 2014.

6. Cobb, C. W. and Douglas, P. H. (1928). "A Theory of Production." American Economic Association, Supplement. pp. 139-167.

7. Eden, Maya and Gaggl, Paul (2014). "The Substitution of ICT capital for Routine Labour: Transitional Dynamics and Long Run Implications”, (mimeo).

8. Eden, Maya and Gaggl, Paul (2016). "On the Welfare Implications of Automation”, UNC Charlotte Economics Working Papers Series, 2016-011.

9. Eggertsson, G. B. and Mehrotra, N. R. (2014). "A Model of Secular Stagnation”, NBER Working Papers, No 20574.

10. Eggertsson, G. B., Mehrotra, N. R., Singh, S. R., and Summers, L. H. (2015). "A Contagious Malady? Open Economy Dimensions of Secular Stagnation", (mimeo).

11. Eggertsson, G. B., Mehrotra, N. R., and Summers, L. H. (2016). "Secular Stagnation in the Open Economy", American Economic Review, Papers and Proceeding, May 2016.

12. Fei, John and Ranis, Gustav (1964). Development of the Labour Surplus Economy: Theory and Policy. Homewood, IL: Richard A. Irwin, Inc.

13. Glaeser, Edvard (2014). "Secular Joblessness", in Teulings, C. and Baldwin, R. (Editors) Secular Stagnation: Facts, Causes, and Cures, A VoxEU.org eBook, CEPR Press, 2014.

14. Gordon, Robert (2012), "Is US Economic Growth Over? Faltering Innovation Confronts the Six Headwinds", NBER Working Paper No. 18315.

15. Gordon, Robert (2014a). "The turtle's progress: Secular stagnation meets the headwinds", in Teulings, C. and Baldwin, R. (Editors) Secular Stagnation: Facts, Causes, and Cures, A VoxEU.org eBook, CEPR Press, 2014. 
16. Gordon, Robert (2014b). “The Demise of U.S. Economic Growth: Restatement, Rebuttal, and Reflections”, NBER Working Paper No. 19895.

17. Gordon, Robert (2014c). "US Economic Growth is Over: The Short Run Meets the Long Run". Growth, Convergence and Income Distribution: The Road from the Brisbane G-20 Summit, Brookings, Think Tank 20, November 2014.

18. Gordon, Robert (2015). "Secular Stagnation: A Supply-Side View", American Economic Review: Papers \& Proceedings, 105(5): 54-59.

19. Hansen, Alvin (1938). "Economic Progress and Declining Population Growth", American Economic Review, Vol. XXIX, No 1, Part I.

20. Komlos, John (2016a). "Has Creative Destruction Become More Destructive?", NBER Working Paper, No 20379.

21. Komlos, John (2016b). "Growth of Income and Welfare in the U.S, 19792011”, NBER Working Paper, No 22211.

22. Kornai, Janos (1993). Transformational Recession: a General Phenomenon Examined through the Example of Hungary's Development, Economie Appliqué, Fall 1993, 46(2): 181-227.

23. Kornai, Janos (1994). Transformational Recession: The Main Causes, Journal of Comparative Economics, No 19, pp. 39-63.

24. Koo, Richard (2003): Balance sheet recession: Japan's struggle with uncharted economics and its global implications, John Wiley \& Sons, Singapore.

25. Koo, Richard (2014). "Balance sheet recession is the reason for secular stagnation”, in Teulings, C. and Baldwin, R. (Editors) Secular Stagnation: Facts, Causes, and Cures, A VoxEU.org eBook, CEPR Press, 2014.

26. Krusell, P., Ohanian, L. E., Rios-Rull, J. V., Violente, G. L. (1997) “CapitalSkill Complementarity and Inequality: A Macroeconomic Analysis", Federal Reserve Bank of Minneapolis, Research Department Staff Report, No 236, p. 67.

27. Lamoreaux, Naomi; Raff, Daniel and Temin, Peter (2002). Beyond Markets and Hierarchies: Toward a New Synthesis of American Business History". NBER Working Papers No 9029, Cambridge, Massachusetts.

28. Lazonick, William (2016). "Innovative Enterprise or Sweatshop Economics? In Search of Foundations of Economic Analysis". The Institute for New Economic Thinking, Working Paper 25.

29. Lewis, Arthur (1954). "Economic development with unlimited supplies of labour.” The Manchester School 22 (2): 139-191.

30. Mansfield, Edward (1965). "Rates of Return from Industrial Research and Development." The American Economic Review. p.310-323.

31. Mansfield, Edward (1968a). Industrial Research and Technological Innovation. New York: 
32. Mansfield, Edward (1968b). Economics of Technological Change. New York: W.W.Norton \& Co inc.

33. Mansfield, Edward at. al (1971). Research and Innovation in the Modern Corporation. New York: Norton.

34. Mansfield, Edward at all (1977). The Production and Application of New Industrial Technology. New York: W.W. Norton and company.

35. Mansfield, Edward at al (1982). Technology Transfer, Productivity, and Economic Policy. New York, London : W.W.Norton and co.

36. Mansfield, Edward (1984). "R \& D and Innovation: Some Empirical Findings." In Griliches (ed) RÆD, Patents, and Productivity. Chicago: N B E $\mathrm{R}$, Chicago University Press.

37. Milanovic, Branko (2016). Global Inequality - A new Approach for the Age of Globalization; The Belknap Press of Harvard University Press; Cambridge Massachusetts, London - England.

38. Mokyr, Joel (2014). "Secular Stagnation? Not in Your Life", in Teulings, C. and Baldwin, R. (Editors) Secular Stagnation: Facts, Causes, and Cures, A VoxEU.org eBook, CEPR Press, 2014.

39. Piketty, Thomas (2014). Capital in $21^{\text {st }}$ Century, The Belknap Press of Harvard University Press, Cambridge, Massachusetts, London, England.

40. Rachel, Lukasz and Smith, Thomas D. (2015). "Secular drivers of the global real interest rate", Staff Working Papers No 571, Bank of England, December 2015.

41. Ranis, Gustav and Fei, John (1961). A Theory of Economic Development. The American Economic Review, 50. 533-565.

42. Rifkin, Jeremy (1995). The End of Work: The Decline of the Global Labour Force and the Dawn of the Post-Market Era, G. P. Putnam's Sons New York.

43. Rifkin, Jeremy (2014). The Zero Marginal Cost Society - The Internet of Things, the Collaborative Commons, and the Eclipse of Capitalism. Pelgrave, Macmillan, 2014.

44. Rodrik, Dany (2011). The Globalization Paradox - Democracy and the Future of World Economy. W. W. Norton and Company, New York, 2011.

45. Rogoff, Kenneth (2015). "Debt Super-Cycle, not Secular Stagnation”, article on VoxEU.org, 25 September, www.voxeu.org/article/debt-supercycle-notsecular-stagnation.

46. Schumpeter, Joseph (1947). Theory of Economic Development;

47. Simon, Herbert (1947). Administrative Behaviour: A Study of Decision Making Process in Administrative Organizations; Macmillan, USA, 1947, p. 259.

48. Solow, Robert (1956). "A Contribution to the Theory of Economic Growth", Quarterly Journal of Economics 70(1), pp. 65-94. 
49. Solow, Robert (1957). "Technical Change and the Aggregate Production Function", Review of Economic and Statistics 39, pp. 312-20.

50. Solow, Robert (1959a). "Investment and Economic Growth: Some Coments". Productivity Meassurement Review, pp. 62-68.

51. Solow, Robert (1959b). "Investment and Technical Progress". In Mathematical Methods in the Social Sciences. (Arrow, J. K., Karlin, S., Suppes, P.), Stanford: Stanford University Press.

52. Solow, Robert (1962a). "Substitution and Fixed Proportion in the Theory of Capital”. Review of Economic Studies, pp. 207-219.

53. Solow, Robert (1962b). "Technical Progress, Capital Formation, and Economic Growth”. The American Economic Review, pp. 76-87.

54. Solow, Robert (1987). “We'd Better Watch Out”. New York Times, 12. July 1987 (Book Reviews, Stephen Cohen and John Zysman: The Myth of Post Industrial Economy). P. 36.

55. Stiglitz, Joseph (2012). The Price of Inequality: How Today's Divided Society Endangers Our Future, W. W. Norton.

56. Storm, Servaas (2017). „The New Normal: Demand, Secular Stagnation and the Vanishing Middle-Class". The Institute for New Economic Thinking, Working Papers 55.

57. Summers, Laurence (2013). "IMF Economic Forum: Policy Responses to Crises", speech at the IMF Fourteenth Annual Research Conference, Washington, DC, 9 November.

58. Summers, Laurence (2014a). "Reflections on the 'New Secular Stagnation Hypothesis"”, in Teulings, C. and Baldwin, R. (Editors) Secular Stagnation: Facts, Causes, and Cures, A VoxEU.org eBook, CEPR Press, 2014.

59. Summers, Laurence (2014b). "U.S. Economic Prospects: Secular Stagnation, Hysteresis, and the Zero Lower Bound”, Business Economics, Vol. 49, No. 2.

60. Summers, Laurence (2015). "Demand Side Secular Stagnation", American Economic Review: Papers \& Proceedings, 105(5): 60-65.

61. Summers, Laurence (2016), "The Age of Secular stagnation: What It Is and What to Do About It", Foreign Affairs, February 2016.

62. Teulings, C. and Baldwin, R. (Editors) Secular Stagnation: Facts, Causes, and Cures, A VoxEU.org eBook, CEPR Press, 2014.

63. Temin, Peter (2015). “The American Dual Economy: Race, Globalization, and the Politics of Exclusion". The Institute for New Economic Thinking, Working Papers 26.

64. Thwaites, Gregory (2015). "Why are interest rates so low? Secular stagnation and relative price of investment goods." Staff Working Papers No 561, Bank of England, November 2015, p. 73.

65. Varoufakis, Yanis (2015). Global Minotaur, Zed Books Ltd, p. 280. 
66. Williamson, Oliver (1985). The Economic Institutions of Capitalism: Firms, Markets, Relational Contracting, Free Press, New York, 1985. 